\title{
Re Brown
}

Newcastle Consistory Court: McClean Ch, April 2008

Exhumation - mistake - delay

The petitioner's late husband died at the age of 50 in 1983 . The petitioner was hospitalised through illness brought about by her grief, and the funeral was arranged by her daughters while she was hospitalised. The burial took place in Alnwick, where the petitioner had lived for just over a year, on a temporary basis with her husband, who had been looking for work. Unknown to the petitioner's daughters, the petitioner and her husband had determined to be buried in Darlington where they had lived for twenty years. The petitioner sought a faculty for the exhumation of her late husband's remains and their re-burial in Darlington. The chancellor considered the decision in Blagdon ${ }^{1}$ and ruled that this was an unusual case - it was not a classic case of 'mistake', although he accepted that there was a mistake in that the daughters acted in ignorance of their parents' wishes, and there was no 'change of mind' in relation to the move to Darlington, as they had lived there for twenty years. The delay was explicable on the basis of a lack of knowledge of whether or how the mistake could be rectified. The faculty was granted. [JG]

doi:10.1017/So956618Xo8001567

\section{Appeal of the Reverend David King \\ Chancery Court of York: Cameron, auditor with assessors, April 2008 Clergy Discipline - conduct unbecoming - penalties - suspension}

The appellant was the incumbent of a benefice in the diocese of York. A clergy discipline tribunal had determined that his conduct had been unbecoming of a clerk in holy orders in respect of his relationship with a woman to whom he was not married. ${ }^{2}$ The tribunal had imposed a penalty amounting to immediate deprivation from his preferment and prohibition from exercise of the function of his orders for four years. The appeal was against penalty only. The appellant claimed that the sentence was excessively severe, took no account of the appellant's pastoral care of his benefice and previous parishes, and did not give credit for the time that he had been suspended from duty pending the determination of the tribunal. The court dismissed all three points of the appeal and upheld the penalty imposed. In dismissing the appeal, the court noted that, while the Clergy Discipline Commission's Guidelines on Penalties mention removal from office 